\title{
THE HISTORICAL SIGNIFICANCE OF WORK WITH ELECTRIC ORGANS FOR THE STUDY OF CHOLINERGIC TRANSMISSION
}

\author{
VICTOR P. WHITTAKER \\ Arbeitsgruppe Neurochemie, Max-Planck-Institut für Biophysikalische Chemie, Postfach 284l, \\ D-3400 Göttingen, F.R.G.
}

\section{A paper in honour of Henry Mcllwain for his contribution to meurochemistry}

\begin{abstract}
The historical significance of work with electric organs for the development of electrobiology and our understanding of the cholinergic synapse at the cell and molecular biological level is traced from its earliest beginning in folk medicine, through the controversy on bioelectricity between Galvani and Volta to the present day, the last decades of which have seen the sequencing of the nicotinic acetylcholine receptor, the isolation and biochemical characterization of the cholinergic vesicle and much else. In the concluding section of the review the continued relevance and usefulness of the electromotor system as a model for future neurobiological research is emphasized.
\end{abstract}

Progress in experimental biology often depends on the selection of a suitable model system. For the mammalian central nervous system this is well illustrated by McIlwain's application of the tissue slice technique to brain tissue. Such slice preparations enable many metabolic processes of importance in the maintenance of cerebral function to be studied under controlled conditions in vitro while retaining a high degree of organization and electrical activity. In the peripheral nervous system, the perfused superior cervical ganglion, the avian ciliary ganglion, but especially the mammalian adrenal medulla and the electromotor synapses of electric fish have provided preparations of comparable value, the adrenal medulla yielding a hypertrophied model of the adrenergic nerve terminal and the electromotor synapse of electric organs a hypertrophied version of the cholinergic neuromuscular junction.

This article aims briefly to survey the historical significance for our understanding of cholinergic synaptic function, particularly in its cell and molecular biological aspects, of the electric organs of certain genera of fish.

Electric organs exist in great variety in unrelated species and have been the products of convergent evolution. They can be divided broadly into two types: the weakly and strongly electric organs. The former continuously emit trains of high frequency discharges which are picked up by electroreceptors on the body surface of the fish; the attenuation or distortion of the signals by objects in the surrounding water enables the fish to form an impression of its environment; this is particularly useful in muddy water. The strongly electric organs are designed to stun faster-moving prey. In some species of this class, e.g. the electric eel, Electrophorus, of the Amazon, the organ may serve both functions. Although weakly electric organs have been studied morphologically and electrophysiologically, the electric organs most investigated are those of the two strongly electric, but otherwise unrelated genera, Electrophorus and the electric ray, Torpedo, an elasmobranch related to sharks, the type species of which, $T$. torpedo (Linn.), is common in the Mediterranean. Some other species of ray have small electric organs in the tail; these are more difficult to classify and have hitherto attracted little attention, but have potential for the future. The same applies to the electric catfish of the Nile, Malapterurus, in which only one giant electromotor neuron on each side controls extensive paired electric organs.

\section{ELECTRIC ORGANS AND BIOELECTRICITY: FROM ARISTOTLE TO BERNSTEIN}

Electric fish were known in ancient times but the nature of their shocks was not understood

The two zoologically unrelated electric fish Torpedo and Malapterurus have been known to Mediterranean people since ancient times; both feature in 
early art (Fig. 1) and the Torpedo in folk medicine (reviewed by Kellaway, 1946; Wu, 1984; Zimmermann, 1985). Torpedo is the classical Latin name of the electric ray and is derived from torpere, to be stiff or numb (hence the English word 'torpid'); the use of the word to denote a self-propelled underwater missile is derivative. Aristotle (384-322 B.C.) in his Historia Animalium and Pliny the Elder (23-70) in his Naturalis Historia both gave accounts of the Torpedo and its application in medicine, Galen (129-199) speculated on the nature of the discharge and Claudian (370-408) wrote an idyll on the unpleasant consequences of hooking a Torpedo when fishing! Numerous ancient authors, Greek, Roman and Arabic, refer to the numbing or paralysing shocks received when handling these fish, but until the nature of electricity began to be understood in the 18 th century these shocks were thought to be caused by some kind of venom or toxin analogous to those of snakes, scorpions or certain plants. No connexion at all was seen with that other natural manifestation of electricity, lightning.

\section{Eighteenth-century scientists discover that the shock is electrical}

Accurate anatomical descriptions of Torpedo began in the 17th century. The German Engelbert Kaempfer (1651-1716) travelled extensively in the near and far East and studied the common torpedo of the Persian Gulf, $T$. panthera (Carrubba and Bowers, 1982). He gives a vivid description of the discharge of the organ: "the numbness induced is not the sort felt in a sleeping limb, but a sudden condition that instantly travels through the touching part and penetrates the citadel of life and breath... In a word, you would think that your major joints were broken and limp, especially those of that member which first received the expelled vapours... So powerful and so swift is the force of the horrid exhalation that like a chill bolt of lightning it shoots through the handler". "Chill", "numb"- the use of these words reminds one of Galen's view of the nature of the shock administered by the electric organ, which was of course known to the scholarly Kaempfer; in accordance with his doctrine that disease was due to an imbalance of the four humours, Galen thought that the shock was a discharge of extreme cold. However, Kaempfer's mention of lightning is prescient.

Among 17th and 18th century descriptions of the torpedo are those of the Italian Lorenzini (fl. 1678) who made careful dissections; he correctly speculated that the electric organ was derived from muscle and thought the shock must be caused by the rapid expulsion of corpuscles by it. Giovanni Borelli (1608-1679) extending Lorenzini's theory thought that the shock was a kind of rapid vibration or blow; this was supported by the influential René de Reaumur (fl. 1714). An even more detailed dissection of the electric organ was made by the English anatomist John Hunter (1728-1793). The first detailed description of the innervation of the electric organ was given by Rudolph Wagner, a Göttingen Professor of zoology (Fig. 2).

The invention of the Leyden jar, a primitive condenser. by van Musschenbroek and von Kleist allowed the electric charges generated by a friction machine to be stored and so enabled much larger discharges to be generated than had previously been possible. The sensations produced by shocks of this kind were soon noticed to be similar to those generated by electric fish. This quickened interest in the latter, which was increased when reports reached Europe and North America of the electric eel (Electrophorus) of the Amazon; the discharge of this fish is much larger than that of the torpedo and may reach $600 \mathrm{~V}$. Critics of the electrical nature of the discharge were finally silenced when Walsh (1725-1795) demonstrated in 1773 that an electric eel could in fact generate a spark. The era of bioelectricity had now begun. Until the advent of the thermionic amplifier in 1920, electric organs provided the only physiological preparation in which membrane potentials could be easily studied and no textbook of physiology in the 19th century was complete without a long chapter on them. A good example is the two-volume textbook by $\mathbf{M}^{\top}$ Kendrick and Stöhr (1888). However, during the final decade of the 18th century, a new controversy broke out, between Galvani (1737-1798) and Volta (1745-1827) on the nature of bioelectricity (for interesting accounts see Rothschuh, 1961; Mauro, 1969; Wu, 1984 and for contemporary speculations, Rothschuh, 1960); Galvani maintained that living cells could generate electricity (Fig. 1) while Volta insisted that the phenomenon observed by Galvani was a purely physical one resulting from the contact of the metallic conductors with moist tissue. Both were correct. Volta was right in saying that Galvani's original demonstration could be explained by the contact of dissimilar metals and did not require the concept of bioelectricity; he built the first battery to prove it. On the other hand, Galvani's later experiments with what we would now call injury potentials and the existence of electric organs were both examples of bioelectricity that Volta could not gainsay: indeed he called his battery an "artificial electric organ". However, the 


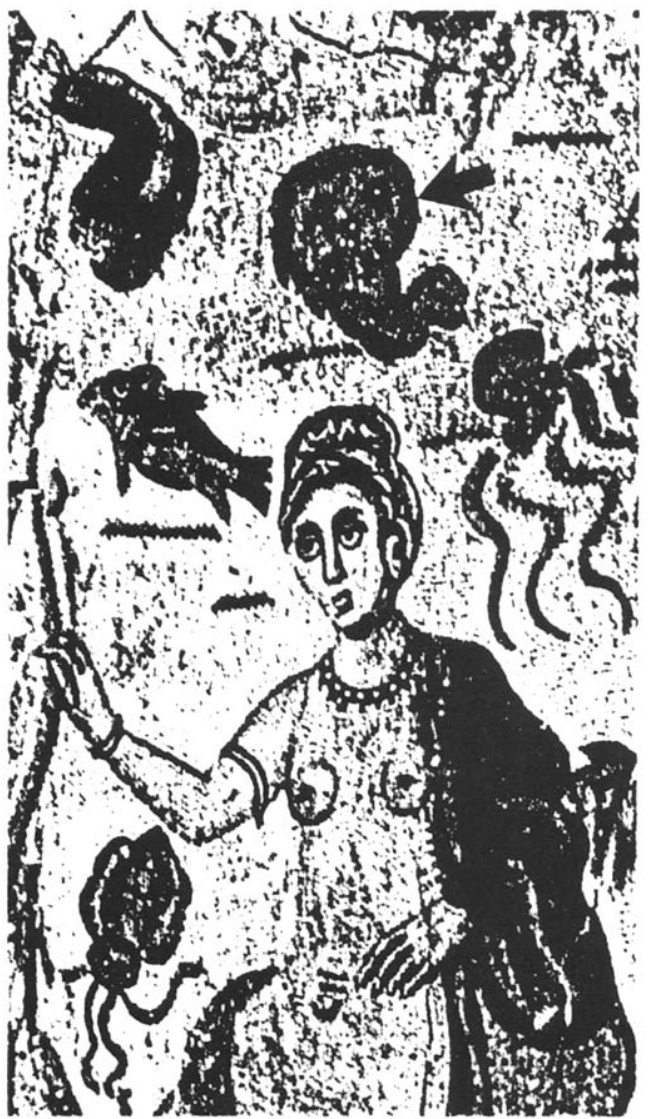

47 \& minimi demum motus in electomctris hactenus inventis in dicia .

Id vero etiam commune habet animalis nostra electricitas cum hujusinodi electricisase, ut nullo pravio artificio, frictione ncmpe, calore, aur hujusmodi aliis indigeat, quibus exciterur, sed parate velati a natura ac prompta jusiter sit, soloque cooeactu se projas. Immo ranta est as agendum prompeitudo in ea animalium electrictestc, qtam experti fuimus, ut si corpore licet cohibente atcingatur vereebralis tubus quo loco est armarus, nihilominus haud raro contractiones se prodant, animali potis. sinum recenter mastato, \& preparato, sxpe autem contingant si idem colibens corpus adversus merallicum folium iea urges tur, ut folii contactus cum nervo e tubo egredienti aut augeztur, aut immutecur, quod nescio 20 de torpedinis elecericitate possit affirmari .

Id porro unum torpedinis maxime, atque affinium animalium proprium, ac peculiare videtur, ut pro arbitrio, ac volun tate extra cutim valeane electricitatem dirigere, atque expellere it2 ut suum illa extra corpus circuitum conficiat, \& tant2 copia, \& vi, ut scintillam, si Physicos audiamus, exhibeat, ut concussionem, vehementemque sensationem inducat, eumque interduin impetum in asimalcula, qux in ipsius circuitus semitain incidunt, faciat, ut eadem vel necet, vel stupida reddat, \& consternara. Verum haec uberiorem forte in hujus census animalibus electricitatis copiam, \& vim designaat, non vero dissimilem naturam; \& forte aliquando inveairi poterunt artificia, quibus hujusmodi effectus in aliis etiam animalibus obtineantur.

Inventx autem a nobis atque indicatz ejusmodi electrici clrcuitus in cxteris animalibus cum rires, \& rationes, tum vix, \& instrumenta aliquam forte lucem circa eumdem in torpedine, affinibusque animalibus circuitum porerunt afferre, \& rursus $2 b$ horum animalium organorum, qux ad id muneris apta sint, diligentiori disquisitione, \& observatione poterunt hec nostra lucem recipere. Instrumenta forte erunt similia, idem eledriet circuitus termini, musculi nempe, \& nervi.

Hac de indole, atque ingenio animalis electricitatis. Pau. ca nunc de ejusdem fonte. Hunc non dissimilem ab eo esse putarem, quem Physiologi ad hac usque tempora pro spiritibus animalibus indicanunt, cerebrum aempe. Licet enim electriciea.

Fig. 1. Left: detail from a Roman mosaic depicting a sea-goddess, apparently wearing a wet T-shirt and surrounded by sea-creatures. The original is in an imperial villa near Piazza Armerina, Sicily. The arrow points to a torpedo. A squid, an octopus, a fish and a dolphin may also be seen. Right: an excerpt from L. Galvani's treatise, De Viribus Electricitatis in Motu Musculari (Bologna, 1794). Lines 16-28 describe the shock of the torpedo-in R. M. Green's (1953) translation, "Moreover, this one thing seems particularly proper and peculiar of the torpedo and cognate animals that at their will and pleasure they can direct electricity outside their skin, and expel it so that it completes its circulation outside the body, and with such quantity and force that it exhibits a spark, if we heed the physicist, so that it produces a concussion and violent sensation and sometimes makes such an impact on the animalcules that fall into the path of its circulation, that it either kills or stupefies and terrifies them".

true origin and nature of bioelectricity remained obscure. A better understanding required the development of a much more sensitive method of detecting weak currents and this was achieved by Du Bois-Reymond (1818-1896).

Using a sensitive galvanometer of his own design that utilized over $5 \mathrm{~km}$ of wire wound in 24,000 turns Du Bois-Reymond was able to detect action currents in muscle and nerve. The development of chemical thermodynamics and its application to the theory of solutions, led to the discovery of diffusion potentials which arise when two solutions containing an ion at different concentrations are separated by a membrane permeable to that ion. This phase culminated in the work of Bernstein (1912) who first correctly postulated that the discharge of the organ arose from a transient increase of the permeability of the innervated membrane to positively charged ions and the resultant asymmetrical distribution of charge across it. 
TRANSMISSION AT THE ELECTROMOTOR SYNAPSE IS CHOLINERGIC

\section{The chemical nature of synaptic transmission}

Interest in electric organs waned after the First World War, largely as a result of the development of the thermionic valve amplifier and its application to electrophysiology by Lucas, Adrian and Cole in the 1920s. This made it possible for the first time to detect action potentials in single nerve and muscle fibres. However, the nature of the link between the propagated action potential in nerve and that in the postsynaptic nerve or muscle which it excites required for its understanding the confluence of two other concepts: that of chemical transmission, of which the chief protagonists were Loewi and Dale, and that of the "generator" or excitatory postsynaptic potential (epsp) as a graded response to transmitter release which triggers an "all-or-nothing" conducted response in the target cell; the main contributors here were Kuffler, Katz and Eccles. Grundfest, in an important review (1957) which summarized his own work and that of others, notably Keynes and Martins-Ferreira (1953), pointed out that the discharge of Torpedo consisted exclusively of summed epsps, whereas that of Electrophorus comprised both epsp and a conducted response: whereas the mature electrocytes of Torpedo are electrically inexcitable and cannot respond with a conducted action potential to a chemically generated epsp, those of Electrophorus can do so.

The close relationship of electrocytes to muscle--.the embryological differentiation of normal-looking myotubes in the electric-organ Anlage into electrocytes had been clearly described, inter alia, by Fritsch (1890) in his important and comprehensive monograph on electric fishes-made it extremely likely that transmission at the electromotor synapse, like that at normal neuromuscular junctions, would prove to be mediated by acetylcholine. That this was so was demonstrated in a now classical series of experiments carried out in Arcachon in 1939 in a brief 3 weeks in June of that year, just before the outbreak of the Second World War. Two of the three protagonists, David Nachmansohn and Wilhelm Feldberg, were German Jews who had emigrated from NationalSocialist Germany.

Nachmansohn's life-long involvement with the electric organ and acetylcholine metabolism began, in collaboration with his student technician, Annette Marnay, in the Laboratoire de Physiologie Générale of the University of the Sorbonne, Paris where, as a refugee from Hitler Germany, he had obtained an appointment in 1934. The classical work of Loewi. Dale and others had strongly indicated that transmission at several synapses, including the neuromuscular junction, involved the release of acetylcholine from the presynaptic nerve terminals and its interaction with receptors in the postsynaptic membrane; Dale had coined the term "cholinergic" to indicate such synapses in contrast to those utilizing noradrenaline in the same way which he called "adrenergic". It had long been known that acetylcholine was rapidly destroyed enzymatically by contact with tissue and blood (Dale, 1914) and could be stabilized in their presence by the addition of eserine in low concentrations (Engelhart and Loewi. 1930; Matthes, 1930). The enzyme from plasma was purified by Stedman et al. (1932) and named by them choline-esterase, later abbreviated to cholinesterase.

\section{The significance of cholinesterase}

High concentrations are present in electric organs. Nachmansohn reasoned that if acetylcholine was indeed a transmitter at the neuromuscular junction, it must be destroyed within the refractory period of muscle, i.e. within a few milliseconds. Marnay and Nachmansohn (1938) examined the cholinesterase activity of frog sartorius muscle in which the motor endplates are confined to one end. They found that the enzyme activity in the innervated portion was several thousand times greater than that of the noninnervated portion and was sufficiently great to bring about the hydrolysis of acetylcholine in the appropriate short time interval. With Lederer, Nachmansohn then showed (Nachmansohn and Lederer, 1939) that Torpedo electric tissue had an even greater cholinesterase activity than innervated muscle. At this stage Nachmansohn still accepted the Loewi-Dale concept of cholinergic transmission and he readily took up an invitation from A. Fessard, a well-known electrophysiologist at the College de France, to accompany him on a June visit to the Station Biologique d'Arcachon, situated on the Bassin d'Arcachon, where Torpedo is abundant, to investigate whether the electromotor synapse utilized acetylcholine as a transmitter, as had recently been demonstrated by Dale for the neuromuscular junction. There they were joined by W. Feldberg, a young co-worker of Dale who was an expert on the bioassay of acetylcholine and its close arterial injection, techniques already used by Dale in his demonstration of cholinergic transmission in muscle. Accounts vary as to how Feldberg became involved in the project. According to a letter from Nachmansohn to J.-P. Changeux. 
which was widely circulated at a conference on the Torpedo organized by the latter in Arcachon in 1976, Fessard asked Dale to provide a co-worker who could do the planned assays of acetylcholine; according to Feldberg himself (letter to the author dated 18 April 1977), he approached Nachmansohn on his own initiative at a Physiological Society Meeting.

The electromotor synapse is shown to be cholinergic. In a mere 3 weeks of research in the summer of 1939 supplemented by some further work in London, the cholinergic nature of the transmission at the electromotor synapse was established. The results were described in a now classical paper (Feldberg and Fessard, 1942; Fig. 2). Three lines of evidence are presented. In the first, extracts of electric organ made under conditions which preserve acetylcholine (presence of eserine, a powerful inhibitor of cholinesterase, or extraction at $\mathrm{pH} 4.0$ ) are shown to contain a substance which contracts the frog's rectus abdominis muscle; the contractions can be matched by acetylcholine and the substance, like acetylcholine, is alkali-labile and destroyed by contact with electric organ tissue or with serum if eserine is not present. It causes acetylcholine-like contractions of the dorsal muscle of the leech, slowing of the frog's heart, a fall in the cat's blood pressure and adrenaline release from the adrenal medulla, and in parallel assays can be matched consistently in its depressor, cardioinhibitory and contractile actions with acetylcholine. Electric organ levels (as acetylcholine) are about $400 \mathrm{nmol} \mathrm{g}^{-1}$, consistent with the lower of the range of values found in later assays, including those utilizing gas chromatography-mass spectrometry (Weiler et al., 1981) in which the presence of acetylcholine is decisively indicated by the mass spectrum. In the second line of evidence, the liberation of what we may now call acetylcholine from the tissue is shown in experiments with organs perfused through the artery accompanying the IInd nerve. Stimulation at $12 \mathrm{~Hz}$ for $3 \mathrm{~min}$ releases aprox. $0.8 \mathrm{nmol}$ acetylcholine $\mathrm{min}^{-1}$. Finally, close arterial injection of $25-1000$ pmol of acetylcholine generates typical postsynaptic potentials analogous to those recorded from muscle endplates. The electromotor junction is thus cholinergic, like the neuromuscular junction.

Nachmansohn felt increasingly insecure in France as the clouds of war began to gather in Europe and in late summer 1939, he left for the U.S.A. and a position in Fulton's Department of Physiology at Yale University, Feldberg had already emigrated, with Dale's help, to England in 1933.

Nachmansohn's theory of excitable tissue. Nachmansohn's views about the role of acetylcholine and N.C.J. 14/3-D
Table 1. Correlation between magnitudes of discharge and cholinesterase activities of electric organs of different species (data from Nachmansohn and Meyerhof, 1941)

\begin{tabular}{lcc}
\hline Species & $\begin{array}{c}\text { Potential of } \\
\text { discharge (V) }\end{array}$ & $\begin{array}{c}\text { Cholinesterase activity } \\
\text { (mg acetylcholine } \\
\text { hydrolysed organ }\end{array}$ \\
\hline Raja undulata & $1-3$ & $0.5-1.0$ \\
Torpedo marmorata & $30-60$ & $50-100$ \\
Gymnotus electricus & $300-800$ & $500-1000$ \\
\hline
\end{tabular}

cholinesterase now began to diverge from those of Dale and Feldberg. Obtaining supplies of electric eel through C. W. Coates, the curator of the New York aquarium, Nachmansohn found that the cholinesterase activity of the electric organ of this species was even higher than that of Torpedo, whereas in the weak electric organ in the tail of the skate the cholinesterase was low (Nachmansohn and Meyerhof, 1941; Table 1). There was thus a kind of proportionality between electrical activity and cholinesterase activity. Nachmansohn soon generalized this into the concept that the synthesis and breakdown of acetylcholine were involved in the activity of all excitable tissues: he held that the basis of the propagated action potential in nerve and muscle was the cyclical synthesis and destruction of acetylcholine within the membrane in the course of which acetylcholine interacted with a "receptor" thus opening the sodium channels and initiating the electrical signal. The action of acetylcholine was transferred from the terminal, and a role in synaptic transmission, to the nerve (and muscle) membrane, and assigned a role in the conduction of the action potential. Nachmansohn presented his case in innumerable lectures and review articles and, definitively, in his book Chemical and Molecular Basis of Nerve Activity (Nachmansohn, 1959). To his hearers he often seemed to lecture more with the skill of a defence lawyer rather than with the objectivity of a research scientist, for the essential correctness of the Dale theory of cholinergic transmission was by now almost universally accepted, even by neurophysiologists like Eccles, who had been strongly opposed to it, and much evidence could be marshalled against Nachmansohn's model.

The organophosphorus anticholinesterases. An important factor in Nachmansohn's career was the discovery of the highly toxic organophosphorus anticholinesterases, the so-called "nerve gases". An interesting account of these substances has been given by Holmstedt (1964). Their highly toxic nature was first noticed in Germany in the thirties (Lange and Krueger, 1932) and they were patented as insecticides; however, they soon attracted the attention 
of the German military authorities and further publication was suppressed. Their existence became known to the British in 1940, after the outbreak of the Second World War; their powerful anticholinesterase action was discovered and correctly identified as the basis of their toxic action (Kilby and Kilby, 1947). This information was passed to the Americans after their entry into the war in 1941. Nachmansohn, as one of the few American scientists with experience in the biochemistry of cholinesterase. was soon brought into the American military research effort; thereafter he was generously financed for the rest of his life and was able to build up a large research team.

Nachmansohn's theory fails to convince his critics. Since Nachmansohn's theory initially derived from his work with electric tissue, it may be appropriate at this point to mention briefly some of the difficulties encountered by it and thus to explain its failure to command general assent in preference to the "classical" theory of Dale, which as already mentioned assigns to acetylcholine the function of acting as a transmitter at a subset of nerve endings designated "cholinergic". First of all, the three main components of the system, acetylcholine, acetylcholinesterase and choline acetyltransferase, vary enormously in their concentration in different parts of the nervous system, may occur in non-excitable tissues and are not always well correlated with each other. Thus acetylcholinesterase is found in relatively high concentration in red cells and in the cerebellum, whereas choline acetyltransferase and acetylcholine (whose distribution correlates far better than either of them do with acetylcholinesterase) are absent or low. By contrast human placenta, a non-excitable tissue, contains considerable amounts of choline acetyltransferase and acetylcholine. The choline acetyltransferase of dorsal roots is only about $3 \%$ of that of ventral roots, yet the general features of the conducted excitation are similar in both roots. The alternative, which ascribes the $3 \%$ of choline acetyltransferase to approx. $3 \%$ of cholinergic motor nerves known from degeneration studies to be present in dorsal roots, seems more plausible. Low concen- tration of cholinergic markers in putative noncholinergic nerves such as the giant axon of the squid may be due to the presence of cholinergic vasodilator fibres which innervate the blood vessels in the nerve sheath.

The presence of cholinergic markers throughout the length of cholinergic neurons cannot be taken as evidence that conduction is "cholinergic" in Nachmansohn's sense since components needed in the nerve terminal have to be made in the cell body and transported to the terminal when they are found in much higher concentration. There is, moreover, experimental evidence for this: placing a ligature around a cholinergic nerve produces an accumulation of choline acetyltransferase and acetylcholine above the ligature.

Nachmansohn laid great stress on the ability of diisopropylphosphofluoridate (DPF) to block nerve conduction. However, very high concentrations had to be used: $10 \mathrm{mM}$ or 100 times those needed to block synaptic transmission and the effect produced is unlike that of DPF's anticholinesterase activity: it is reversible on washing. That organophosphorus anticholinesterases can have actions on nerves other than to inhibit their cholinesterase is shown by the ability of some of them including DPF to produce demyelination.

Nachmansohn and his group did not get very far in characterizing the fourth component of his scheme, the receptor for acetylcholine. It is now known that there are two types of receptor, muscarinic and nicotinic, which can be distinguished by appropriate ligands. Again, the binding of these ligands to nervous tissue is highly selective indicating a nonuniform distribution of cholinoceptive as well as cholinergic function. Neither of these receptors are identical in distribution to the sodium channel, as required by the Nachmansohn model.

It is difficult to avoid the conclusion that Nachmansohn, in spite of his early medical training, had little instinct for the subtleties of biological systems and tended to be too simplistic in the interpretation of the data. Thus, he regarded inhibitors like DPF as completely specific for cholinesterase in

Fig. 2. (facing page) Top and bottom right: the first accurate description of the innervation of the electric organ of Torpedo was given by the Göttingen Professor of Zoology Rudolph Wagner (1847). Wagner did his work in Pisa with $T$. torpedo (occellata) and $T$. marmorata, caught by fishermen off Viareggio. In Wagner's time, Göttingen was in the Kingdom of Hanover, but the link with the British crown had been severed by the accession of Queen Victoria in 1837. The Dieterichsche Buchhandlung is still in business. Bottom left: title page of a classical paper: Feldberg and Fessard's (1942) demonstration that the electromotor synapse is cholinergic. Nachmansohn never forgave Feldberg for omitting his name from the paper. 


\section{ABHANDLUNGEN}

\author{
DE:
}

\section{KÖNIGLICHEN GESELLSCH.AFT DER WISSE.XSCHAFTEN}

Z U G ÖT I Y G E.

DEITTER BAVD.

VON DEN JAHRF.N 1845-154:

YIT DIEI ECPTEM - LXD ZWEI sTEINOWCCKTAFEI.X.
Uber dea reineres Ban

des elektrischen Organs im Zitterrochen.

\section{Dr. Rudolph Wagner.}

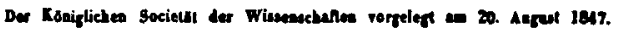

Mie

in 2uurroshen (Torpedo) bebeen sick seit Bualer ') vor beinabe 80 Jahrea die ersiea geasapren Uatersuchunges gab, bis auf Delle (biajes), Valeotia? and Paolo Sari') in der

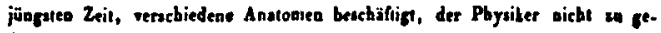

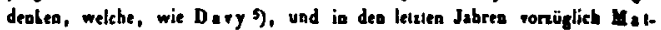
teveci \%, acch gelegentliche Bemertuoges über die sostomiscber Verhältoices gabes. Gleichwobl siad wir soch weit davon eariferot, eive rollatundige Keapi-

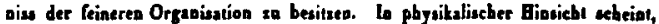
asch dem regeowänigen Stande der Eleturizitäustebre, suaiehu sicbu Reoes

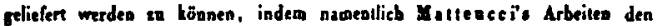
Gegeasiand siemlich abgeschlossen baber, welche vich an Faraday's 7 frübere

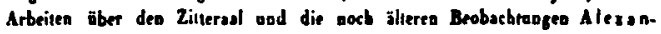

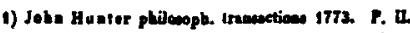

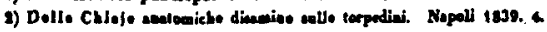

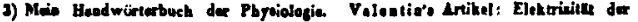
Thion. B. L. S 281.

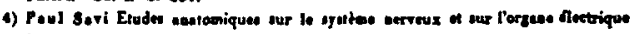

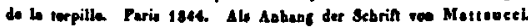

D) Huaphry Dery is philowopbial trasectioss 1829.

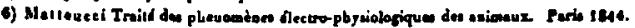
C Foraday in philosoplice! tranesetion 1839.
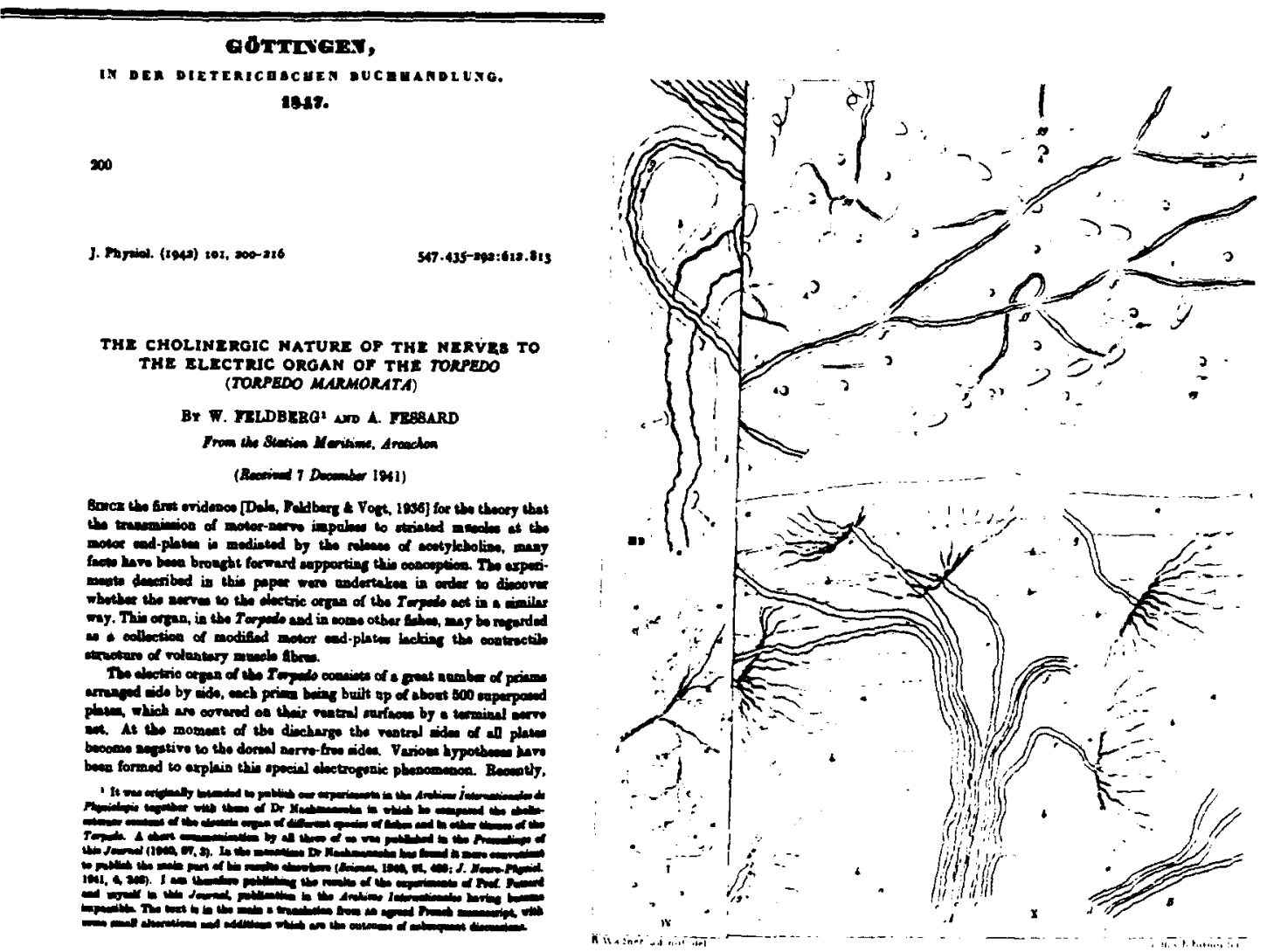

Fig. 2 

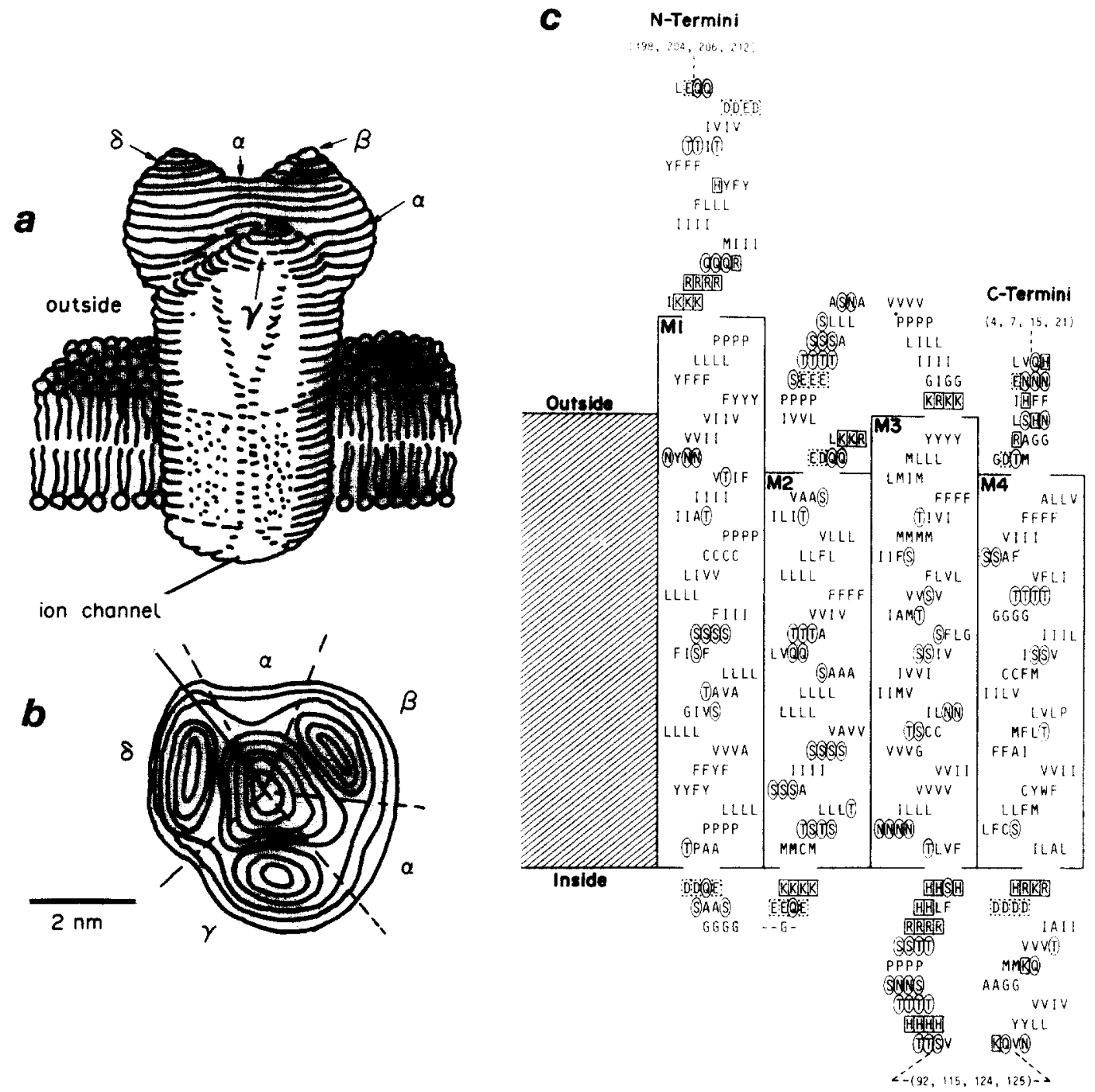

Fig. 3. The structure of the nicotinic acetylcholine receptor (Zingsheim et al., 1982; Kistler et al., 1982). (a) The receptor forms a ligand-activated ion channel through the membrane. (b) Of the four polypeptides making up the channel, one (the $\alpha$-subunit) is repeated and is the ligand binding-site. (c) Each polypeptide (from left to right, $\alpha$ to $\delta$ ) has four membrane-spanning regions connected by hydrophilic loops; there is a high degree of homology between them (Noda et al., 1983).

no matter what concentration; he seemed unaware of the complex structure of the nerve sheath with its complement of cholinergic vasodilator fibres and cholinesterase-containing Schwann cells, or that dorsal roots were not necessarily purely sensory.

Lack of a definitive assessment of Nachmansohn's contribution. A definitive account of Nachmansohn's contribution to neurochemistry has yet to be written. His death, in 1983, called forth several tributes, which, inevitably eulogistic, fail adequately to set the advances of his group against the background of what had been and was being achieved elswhere. Changeux's (1985) account is valuable, but unfortunately lacks references and contains some errors. Thus, Nachmansohn was by no means the first neurochemist to achieve the enzymatic synthesis of a neurotransmitter in vitro (Changeux, 1985, p. 16); the Stedmans had already done this and it was the work of Lipmann and Lynen which led to the identification of the acyl donor, acetylcoenzyme A. In view of the 
wartime British work on DPF just mentioned, it is certainly not correct to state that "DPF was thought by most pharmacologists to exert a general toxic effect" (Changeux, 1985, p. 23). The concept of two active sites in the active centre of acetylcholinesterase (Wilson and Bergmann, 1950) one acting on the ester link, the other binding to the positively charged nitrogen of the substrate (Changeux, 1985, p. 21) was anticipated and independently formulated by Adams and Whittaker $(1949,1950)$ (reviewed by Whittaker, 1951, 1987). The second and definitive of these papers, it may be added, was greatly delayed in publication, as can be verified from the dates of submission, by the intervention of a special number of the journal devoted to Meyerhof, and edited by Nachmansohn! The discovery of the reactivating effect of hydroxylamine on the alkylphosphorylated enzyme (Wilson, 1951; Changeux, 1985, p. 22) was made at a time when the alkylphosphorylation of esterases by organophosphorus inhibitors and their spontaneous reactivation was being studied intensively by numerous workers, including Aldridge, Davies, Green, Hartley and Kilby in the U.K. and Balls and Jansen in the U.S.A. Several groups including that of Davies at the U.K. Chemical Defence Experimental Establishment at Porton Down (Davies and Green, 1956; Childs et al., 1956) tested large numbers of oximes in an effort to define the optimum structure for reactivation, independently discovering 2-pyridine aldoxime as a potent reactivator of cholinesterase, but the publication of some of this work was delayed for reasons of military security.

The nicotinic acetylcholine receptor. It became apparent that electric tissue, with its abundant cholinergic innervation, should be an excellent source of the acetylcholine receptor, the hypothetical ion channel in the postsynaptic cholinoceptive membrane allowing the movement across it, in response to combination with the transmitter, of univalent positive ions $\left(\mathrm{Na}^{+}\right.$and $\left.\mathrm{K}^{+}\right)$, and the generation of the epsp. Early, unsuccessful, attempts at isolation were made by Chagas, Ehrenpreis, De Robertis and others, but a landmark experiment was that performed by Kasai and Changeux (1971) in which preparations of "microsacs"--identified as pinched off invaginations of the postsynaptic plasma membranes of electrocytes-made in a medium containing ${ }^{23} \mathrm{Na}$ and then transferred to a ${ }^{23} \mathrm{Na}$-free solution showed a release of ${ }^{23} \mathrm{Na}$ which was stimulated by acetylcholine and its agonists. The original work was done with preparations from eel, but later, Torpedo electric organ has been used in preference, since it has about 100 times more acetylcholine receptor per unit weight than eel. This is a consequence of the much larger area of synaptic contact in the latter.

In the early sixties, four main groups of investigators advanced our knowledge of the acetylcholine receptor, those of Heilbronn, Karlin, Changeux and Raftery. The last-named group situated on the American West coast, found Torpedo californica an ideal source material. The discovery that certain snake toxins, notably $\alpha$-bungarotoxin and a similar toxin from the venom of the cobra Naja naja were powerful receptor blockers enabled the receptor to be isolated. Heilbronn and co-workers (Karlsson et al., 1972) pioneered the use of affinity chromatography, using columns of Sepharose to which Naja naja venom was covalently bound. This venom was used in preference to $\alpha$-bungarotoxin because its lower affinity enabled the receptor to be eluted from the column at high ionic strength. Interestingly, Professor Heilbronn's great-great-uncle, F. G. J. Henle (1809-1885), best known for his eponymous kidney loops, also worked on Torpedo (E. Heilbronn, personal communication).

As soon as purified receptor became available, antisera were raised to it in rabbits initially for the purpose of immunochemical characterization of the molecule. Patrick and Lindstrom (1973), and independently, Heilbronn and Mattsson (1974) then noticed that the rabbits developed hind-limb paralysis. This condition resembled the human disease myasthenia gravis and was referred to as experimental autoimmune myasthenia gravis. There is now an immense literature on this subject (Toyka, 1988), and it is recognized that the commonest form of the disease is an autoimmune condition arising from the release of the normally membrane-bound receptor into the circulation and the formation of antibodies to it which interfere with neuromuscular transmission. In a given patient there is a reasonably good correlation between the increasing severity of the disease and the rise in circulating anti-receptor antibodies, but between patients the correlation is often poor. Forms of myasthenia are now recognized which involve impairment of presynaptic transmitter release. Subsequent work on the characterization of the receptor protein culminating in the use of the recombinant DNA technique by Numa and his group to sequence the receptor subunits, has been one of the great success stories of modern molecular neurobiology (reviewed by Maelicke, 1984, 1988). Briefly, the receptor consists of five subunits, two $\alpha \mathrm{s}$ and one $\beta, \gamma$ and $\delta$ subunit (Fig. 3). These show considerable homology; each one traverses the membrane four times and the receptor is composed of a cluster of all 


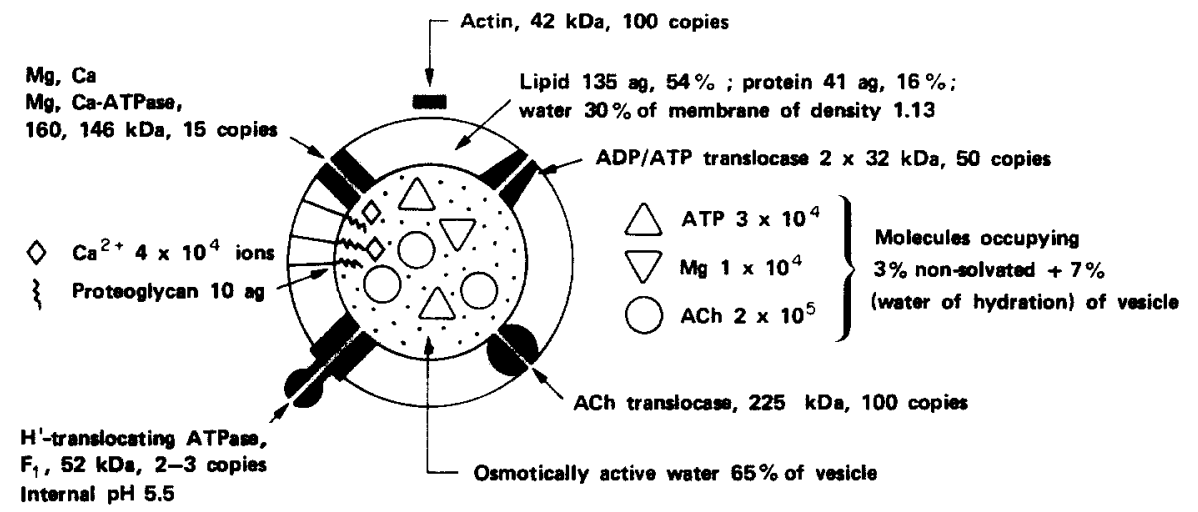

Fig. 4. Summary of one current view (Whittaker, 1984) of the structure of the cholinergic synaptic vesicle of the electromotor nerve terminal. ACh, acetylcholine; $\mathrm{ag}=10^{-18} \mathrm{~g}$. ACh uptake is a two-stage process, involving a proton gradient generated by a proton-translocating ATPase.

five forming a funnel-shaped channel through which univalent ions can move when the ligand attaches itself to the two $\alpha$-subunits; however, the precise conformational changes which open the channel and are responsible for desensitization by the agonist still elude precise definition, though one theory is that the subunits twist relative to each other rather like an iris diaphragm (Kistler et al., 1982).

The cell biology of the presynaptic nerve terminals. The use of Torpedo electric organ to study the cell and molecular biology of the synthesis, storage and release of acetylcholine began in the early sixties in V. P. Whittaker's group in the Institute of Animal Physiology, Babraham, soon after his discovery of the synaptosome and his isolation of homogeneous preparations of presynaptic vesicles from brain cortex. The stimulus was provided by a colleague, R. D. Keynes, who was working on heat production in the electric organ of Torpedo in a neighbouring laboratory. This resulted in the first papers on the isolation of purely cholinergic synaptic vesicles from this tissue (Sheridan and Whittaker, 1964; Sheridan et al., 1966). This work continued through the seventies and eighties as Whittaker moved, first to Cambridge University and then to Göttingen and has led to a fairly complete understanding of the structure (Fig. 4), function and life-cycle of the cholinergic synaptic vesicle, and its role in the exocytosis of transmitter in response to stimulation (reviewed by Whittaker, 1984, 1987a, b, c). Less is known about the presynaptic plasma membrane, but here too, Torpedo electric organs are an excellent source and good progress is being made in the isolation of the high-affinity choline transporter (Ducis and Whittaker, 1985), transmitter related gangliosidic surface antigens (reviewed by Whittaker and Borroni, 1988 ) and much else. The electric organ is also a rich source of a protein, calelectrin (Südhof et al., 1985) which binds to membranes in a $\mathrm{Ca}^{2+}$-dependent manner. Antisera to this protein cross-react with similar proteins in other tissues-including mammalian tissues--and this has led to the identification of a new class of $\mathrm{Ca}^{2+}$-regulated lipid-binding proteins (Südhof et al., 1984) for which the name annexins has also been proposed (Geisow, 1986). Some members of the group have been sequenced (Crompton et al., 1988; Südhof et al., 1988).

\section{FUTURE PROSPECTS}

It seems appropriate to conclude this historical review by a glimpse into the future. Figure 5 summarizes, in diagrammatic form, the various parts of the electromotor system: to the left are lines of work which are well advanced or completed; to the right are those which are still in an early stage of development. Some of the problems mentioned are being studied in other model systems, sometimes more effectively than in Torpedo, and, as with all model systems, the generality of the findings has to be tested. Nevertheless, the electromotor system continues to offer some unique advantages.

The electric lobes-prominent paired lobes on the dorsal surface of the brain stem just behind the cerebellum--weigh $300-400 \mathrm{mg}$ in a large specimen; $50 \%$ of their mass is made up of the large cell bodies of the electromotor neurons. These are packed with pigment granules, mitochondria, rough and smooth surfaced endoplasmic reticulum, vesicles and polysomes, giving a picture of intense synthetic activity - 


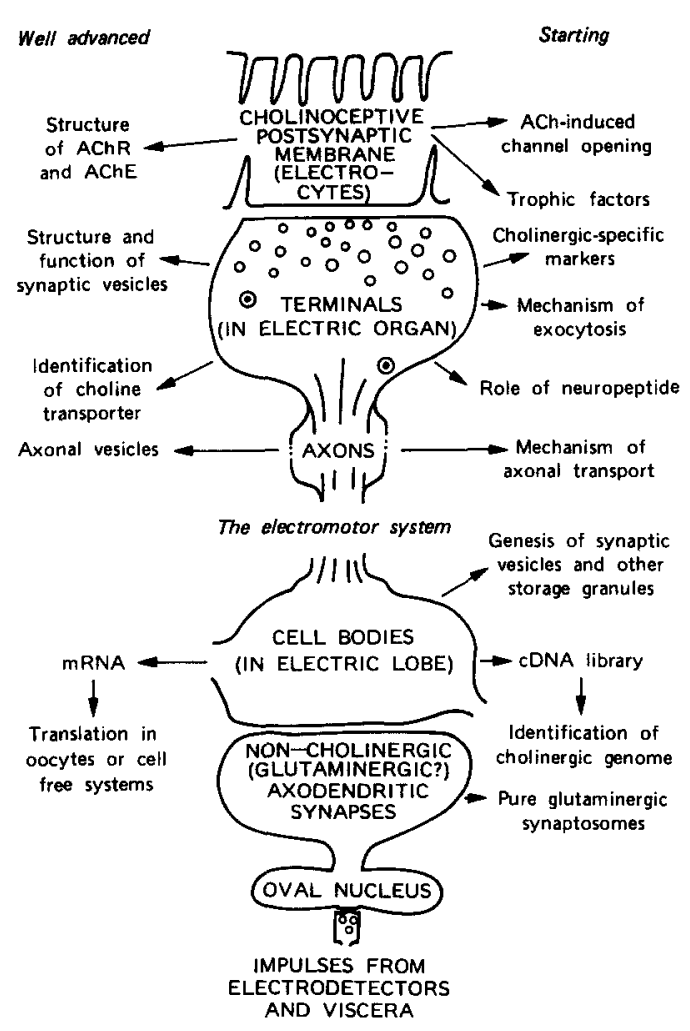

Fig. 5. Diagram of the electromotor system showing (left) problems that are largely solved and (right) those that have only just started (Whittaker, 1987).

understandable when one considers that these cells must maintain over 30 times their own volume of presynaptic nerve terminal. This material should be excellent for tracing the genesis and addressing of synaptic and other storage vesicles, the synthesis of presynaptic proteins and (Schmid and Girou, 1987) the identification of those parts of the genome responsible for cholinergic function. Synapses in these lobes are of only one type: non-cholinergic (probably glutamergic); synaptosomes derived from them should be an excellent source material for investigating this type of ending.

The eight large electromotor nerves have been used to study axonal transport in this purely cholinergic system (Davies, 1978) but there is much to do especially in distinguishing between the different types of storage vesicle transported (Agoston and Conlon, 1986; Agoston et al., 1989) and the mechanisms involved. At the terminal, it has recently been established that two neuropeptides, a VIP- and a GRP-like neuropeptide (Agoston and Conlon, 1986; Agoston and Shaw, 1989) are present in this neuron and are packaged in granules distinct from synaptic vesicles. Although, as previously mentioned, we now have a good understanding of the structure and function of the synaptic vesicle and its recycling at the terminal, the mechanism of exocytosis is still far from being understood.

One of the most important-but most neglectedaspects of the synapse is the presynaptic plasma membrane. Its complex structure can be inferred from the multiplicity of the functions it performs, which include the uptake of molecules needed for energy metabolism and transmitter synthesis, conducting the nerve impulse into the terminal region, permitting the inflow of $\mathrm{Ca}^{2+}$ into the terminal in response to this invasion, regulating transmitter release through autoreceptors, recognizing and adhering to the postsynaptic membrane, and detecting trophic factors needed for the expression and maintenance of cholinergic function. Presynaptic plasma membranes may be isolated in bulk from electric tissue; the high-affinity choline transporter has been isolated and reconstituted in an artificial membrane (Ducis and Whittaker, 1985), cholinergic-specific surface antigens have been identified and partially characterized (Whittaker and Borroni, 1988) and trophic factors have been identified but not as yet fully characterized (Richardson et al., 1985). There is thus little doubt that this model system will continue to influence the development of neurobiology for many years to come.

\section{REFERENCES}

Adams D. and Whittaker V. P. (1949) The cholinesterases of human blood. I. The specificity of the plasma enzyme and its relation to the erythrocyte cholinesterase. Biochim. biophys. Acta 3, 358-366.

Adams D. and Whittaker V. P. (1950) The cholinesterases of human blood. II. The forces acting between enzyme and substrate. Biochim. biophys. Acta 4, 543-558.

Agoston D. V. and Conlon M. J. (1986) Presence of vasoactive intestinal polypeptide-like immunoreactivity in the cholinergic electromotor system of Torpedo marmorata. J. Neurochem. 47, 445-453.

Agoston D. V. and Shaw C. (1989) The presence of gastrinreleasing peptide-like immunoreactivity in the cholinergic electromotor neurons of Torpedo marmorata. Submitted to J. Neurochem.

Agoston D. V., Dowe G. H. C. and Whittaker V. P. (1989) Isolation and characterization of secretory granules storing a vasoactive intestinal polypeptide-likepeptide in Torpedo cholinergic electromotor neurons. $J$. Neurochem. In press.

Bernstein J. (1912) Elektrobiologie. Vieweg, Braunschweig.

Carruba R. W. and Bowers J. Z. (1982) Engelberg Kaempfer's first report of the torpedo fish of the Persian Gulf in the late seventeenth century. J. hist. Biol. 15, 263-274. 
Changeux J. P. (1985) David Nachmansohn (1899-1983): a pioneer of neurochemistry. In: Molecular Basis of Nerve Activity (Changeux J. P., Hucho F., Maelicke A. and Neumann E., eds), p. 1 -32. de Gruyter, Berlin.

Childs A. F., Davies D. R., Green A. L., and Rutland J. P. (1955) The reactivation by oximes and hydroxamic acids of cholinesterase inhibited by organo-phosphorus compounds. Br. J. Pharmac. 10, 462-465.

Crompton M. R., Owens R. J., Totty N. F., Moss S. E., Waterfield M. D. and Crumpton M. J. (1988) Primary structure of the human, membrane-associated $\mathrm{Ca}^{2+}$-binding protein $\mathrm{p} 68$ : a novel member of a protein family. $E M B O J .7,2127$.

Dale H. H. (1914) The action of certain esters and ethers of choline and their relation to muscarine. J. Pharmac. exp. Ther. 6, 147-190.

Davies D. R. and Green A. L. (1956) The kinetics of reactivation, by oximes, of cholinesterase inhibited by organophosphorus compounds. Biochem. J. 63, 529-535.

Davies L. P. (1978) ATP in cholinergic nerves: evidence for the axonal transport of a stable pool. Exp. Brain Res. 33, $149-157$.

Ducis I. and Whittaker V.P. (1985) High-affinity, sodiumgradient-dependent transport of choline into vesiculated plasma membrane fragments from the electric organ of Torpedo marmorata and reconstitution of the solubilized transporter into liposomes. Biochim. biophys. Acta 815, 109-127.

Engelhart E. and Loewi O. (1930) Fermentative Azetylcholinspaltung im Blut und ihre Hemmung durch Physostigmine. Naunyn-Schmiedeberg's Arch. exp. Path. Pharmak, 150, 1-13.

Feldberg W. and Fessard A. (1942) The cholinergic nature of the nerves to the electric organ of the torpedo (Torpedo marmorata). J. Physiol. 101, 200-216.

Fritsch G. (1890) Die elektrischen Fische. Von Veit, Leipzig.

Geisow M. J. (1986) Common domain structure of $\mathrm{Ca}^{2+}$ and lipid-binding proteins. FEBS Lett. 203, 99 103.

Grundfest H. (1957) The mechanism of discharge of the electric organs in relation to general and comparative electrophysiology. Prog. Biophys, biophys, Chem. 7, 1-85.

Heilbronn E. and Mattsson C. (1974) The nicotinic cholinergic receptor protein: improved purification method, preliminary amino acid composition, and observed autoimmune response. $J$. Neurochem. 22, 315317.

Holmstedt B. (1964) Structure-activity relationship of the organophosphorus anticholinesterase agents. Handb. exp. Pharmac. 15, 428-485.

Karlsson F., Heilbronn E. and Widlund L. (1972) Isolation of the nicotinic acetylcholine receptor by biospecific chromatography on insolubilized Naja naja neurotoxin. FEBS Lett. 28, 107-111.

Kasai M. and Changeux J. P. (1971) In vitro excitation of purified membrane fragments by cholinergic agonists. I. Pharmacological properties of the excitable membrane fragments. J. membr. Biol. 6, 1-23.

Kellaway P. (1946) The part played by electric fish in the early history of bioelectricity and electrotherapy. Bull. Hist. Med. 20, 112-137.

Keynes R. D. and Martins-Ferreira H. (1953) Membrane potentials in the electroplates of the electric eel. J. Physiol. 119, 315351.

Kilby B. A. and Kilby M. (1947) The toxicity of alkyl fluorophosphonates and related compounds. Br. J. Pharmac. 2, 234-240.
Kistler J., Stroud R. M., Klymkowsky M. W., Lalancette R. A. and Fairclough R. H. (1982) Structure and function of an acetylcholine receptor. Biophys. J. 37, 371383 .

Lange W. and von Krueger G. (1932) Über Ester der Monofluorphosphorsäure. Ber. dt. chem. Ges. 65, 1598.1601.

Maelicke A. (1984) Biochemical aspects of cholinergic excitation. Angew. Chem. 23, 195221.

Maelicke A. (1988) Structure and function of the nicotinic acetylcholine receptor. Handh. exp. Pharmac. 68, 267313.

Marnay A. and Nachmansohn D. (1937) Sur la répartition de la cholinestérase dans le muscle couturier de la grenouille. C.r. Soc. Biol. Paris 125, 4143.

Marnay A. and Nachmansohn D. (1938) Cholinesterase in voluntary muscle. $J$. Physiol. 92, 37-47.

Matthes K. (1930) The action of blood on acetylcholine. J. Physiol. 70, 338-348.

Mauro A. (1969) The role of the voltaic pile in the Galvani-Volta controversy concerning animal vs. metallic electricity. J. Hist. Med. allied Sci. 24, 140-150.

$\mathrm{M}^{\prime}$ Kendrick J. G, and Stöhr P. (1888) A Text Book of Physiology. McLehose, Glasgow.

Nachmansohn D. (1959) Chemical and Molecular Basis of Nerve Activity. Academic Press, New York.

Nachmansohn D. and Lederer E. (1939) Sur la biochimie de la cholinestérase. Bull. Soc. Biol., Paris 21, 797-808.

Nachmansohn D. and Meyerhof B. (1941) Relation between electrical changes during nerve activity and concentration of cholinesterase. J. Neurophysiol. 4, 348-361.

Noda M., Takahashi H., Tanabe T., Toyasato M., Kikyotani S., Furutani Y, Hirose T., Takashima H., Inayama S., Miyata T. and Numa S. (1983) Structural homogeneity of Torpedo californica acetylcholine receptor subunits. Nature, Lond. 302, 528532.

Patrick J. and Lindstrom J. M. (1973) Autoimmune response to acetylcholine receptor. Science 180, 871-872.

Richardson G. P., Rinschen B. and Fox G. Q. (1985) Torpedo electromotor system development: developmentally regulated neuronotrophic activities of electric organ tissue. J. comp. Neurol. 231, 339-352.

Rothschuh K. E. (1960) Von der Idee bis zum Nachweis der tierischen Elektrizität. Sudhoffs Arch. Gesch. Med. Naturn'iss. 44, 25-44.

Rothschuh K. E. (1961) Die neurophysiologischen Beiträge von Galvani und Volta. Proc. Int. Symp. Hist. Neurol., Varenna.

Schmid D. W, and Girou C. (1987) Cloning of cDNA derived from mRNA of the electric lobe of Torpedo marmorata and selection of putative cholinergic-specific sequences. $J$. Neurochem. 48, 307-312.

Sheridan M. N. and Whittaker V. P. (1964) Isolated synaptic vesicles: morphology and acetylcholine content. J. Physiol. 175, 25-26P.

Sheridan M. N., Whittaker V. P. and Israël M. (1966) The subcellular fractionation of the electric organ of Torpedo. Z. Zellforsch. 74, 29I-307.

Stedman E., Stedman E. and Easson L. H. (1932) Cholineesterase. An enzyme present in the blood-serum of the horse. Biochem. J. 26, 2056-2066.

Südhof T. C., Walker J. H. and Fritsche U. (1985) Characterization of calelectrin, a $\mathrm{Ca}^{2+}$-binding protein isolated from the electric organ of Torpedo marmorata. J. Neurochem. 44, 1302-1307.

Südhof T. C., Ebbecke M., Walker J. H., Fritsche U. and 
Boustead C. (1984) Isolation of mammalian calelectrins: a new class of ubiquitous $\mathrm{Ca}^{2+}$-regulated proteins. Biochemistry 23, 1103-1109.

Südhof T. C., Slaughter C. A., Leznicki I., Barjon P. and Reynolds G. A. (1988) Human 67-dKa calelectrin contains a duplication of four repeats found in 35-kDa lipocortins. Proc. natn. Acad. Sci. U.S.A. 85, $664-668$.

Toyka K. V. (1988) Disorders of cholinergic synapses in the peripheral nervous system. Handb. exp. Pharmac. 68, 695-722.

Wagner R. (1847) Über den feineren Bau des elektrischen Organs im Zitterrochen. Abh. Königl. Ges. Wiss. 3, 141-164.

Weiler M., Roed I. S. and Whittaker V. P. (1982) The kinetics of acetylcholine turnover in a resting cholinergic nerve terminal and the magnitude of the cytoplasmic compartment. $J$. Neurochem. 38, 1187-1191.

Whittaker V. P. (1951) Specificity, mode of action and distribution of cholinesterases. Physiol. Rev. 31, 312-343.

Whittaker V. P. (1984) The structure and function of cholinergic synaptic vesicles. Biochem. Soc. Trans. 12, 561-576.

Whittaker V. P. (1987a) Cholinergic function in the nineties: advantages of work with a model system. Neurochem. Res. 12, 121-128.
Whittaker V. P. (1987) Cholinergic synaptic vesicles from the electromotor nerve terminals of Torpedo: composition and life cycle. Ann. N.Y. Acad. Sci. 493, 77-91.

Whittaker V. P. (1987) Cholinergic transmission: past adventures and future prospects. In: Cellular and Molecular Basis for Cholinergic Function (Dowdall M. J. and Hawthorne J. N., eds), pp. 495-512. Ellis Horwood, Chichester.

Whittaker V. P. and Borroni E. (1988) Cholinergic-specific antigens. Handb. exp. Pharmac. 68, 447-463.

Wilson I. B. (1951) Acetylcholinesterase: XI Reversibility of tetraethyl pyrophosphate inhibition. J. biol. Chem. 190, 111-117.

Wilson I. B. and Bergmann F. (1950) Acetylcholinesterase. VIII Dissociation constants of the active groups. J. biol. Chem. 186, 683-692.

Wu C. H. (1984) Electric fish and the discovery of animal electricity. Am. Scient, 72, 598-607.

Zimmermann H. (1985) Die elektrischen Fische und die Neurobiologie: über die Bedeutung einer naturgeschichtlichen Kuriosität für die Entwicklung einer Wissenschaft. Funkt. Biol. Med. 4, 156-172.

Zingsheim H. P., Barrantes F. J., Franke J., Hänicke W. and Neugebauer D. CH. (1982) Direct structural localization sites on an $\mathrm{ACh}$ receptor protein. Nature, Lond. 299, 81-84. 